\title{
LAI Improved to Dry Forest in Semiarid of the Brazil
}

\author{
Josiclêda Domiciano Galvíncio*1, Magna Soelma Beserra de Moura², Thieres George Freire da Silva ${ }^{3}$, \\ Bernardo Barbosa da Silva ${ }^{4}$, Carine Rosa Naue ${ }^{4}$
}

First, fourth and fifth of Departamento de Ciências Geográficas, Universidade Federal de Pernambuco. Laboratório de Sensoriamento Remoto e Geoprocessamento. Recife-Pernambuco-Brazil

Second of Empresa Brasileira de Pesquisa Agropecuária - EMBRAPA. Petrolina-Pernambuco-Brazil

Third of Unidade Acadêmica de Serra Talhada, Universidade Federal Rural de Pernambuco, Fazenda Saco, s/n, CEP 56900-000, Serra Talhada, Pernambuco, Brazil

"1josicleda@hotmail.com; ${ }^{2}$ magna_upa@hotmail.com; thieres_freire@yahoo.com.br; bernardoufpe@gmail.com; crnaue@gmail.com

\begin{abstract}
Savannas are globally important ecosystems of great significance to human economies. Savannas exist in waterlimited regions which forces tree canopies open and heterogeneous. The open canopy structure allows grass to co-dominate in the savannas by occupying different niches in space and time. Leaf area index (LAI) and fraction of photosynthetically active radiation absorbed by vegetation (FPAR) characterize vegetation canopy functioning and energy absorption capacity. LAI and FPAR are key parameters in most ecosystem productivity models and global models of climate, hydrology, biogeochemistry and ecology. Given the above, this study aimed to develop an equation of LAI calibrated by savannah in semiarid northeastern Brazil and proposed a model to better estimate the LAI for dry forest, such as the savanna (Caatinga). The model developed in this study may be used to improve the estimates of Leaf Area Index [LAI] in dry forest with NDVI. One model for savanna-specific of leaf area index (LAI) has been developed. The use of S Curve statistical methods to calibrate the leaf area index (LAI) proved to be an efficient method. The model development gives good results in most of the LAI range known for Caatinga stands in Northeast of Brazil. The Root Mean Square Error (RMSE) calculated on an independent LAI dataset was 0.10 , which is about $6 \%$ of the average measured LAI. This method offers a simple and operational alternative to application of complex and computationally intensive techniques, and could be used to design other species-specific LAIs. This study reinforces the importance of developing models to better estimate the LAI in different ecosystems since there are no similarities of the LAI between dry and humid climate.
\end{abstract}

Keywords

Dry Ecosystems; Development Model; Fieldspec; Savannas

\section{Introduction}

Tropical savannas cover about one-eighth of the global land surface (Giambelluca et al., 2009) and are characterized by high plant species diversity. The livestock grazing on tropical savannas is the world's most extensive land use. The 1960s, however, marked the beginning of the expansion of large-scale agriculture and planted pastures across the savannas in Brazil (Caatinga e Cerrado). Despite its extent, biotic richness, and vulnerability to impacts of human activities, this biome has received relatively little attention from researchers in comparison with tropical rain forests. Savanna covers about $45 \%$ of the area of South America (Scholes \& Archer, 1997), most of which is composed of the Cerrado that is an important regulator of energy and mass exchange with the atmosphere (Miranda et al., 1997). However, the interactions between grasses and deeply rooted trees and shrubs and the effects of these interactions on energy and water balances are not well understood (Meinzer et al., 1999).

Savannas that are globally important ecosystems of great significance to human economies (Sankaran et al. 2005) exist in water-limited regions, which forces tree canopies open and heterogeneous (Eagleson \& Segarra, 1985), (Ryu \& Science, 2010). The open canopy structure allows grass to co-dominate in the savannas by occupying different niches in space and time. The co-dominance of trees and grass defines the functions and metabolisms in the savanna ecosystems (Higgins, Bond, \& Trollope, 2000);(House et al., 2003). However, how to quantify canopy architecture and monitor structure, function, and metabolism in savanna ecosystems remains challenging.

The importance of studying vegetation dynamics has been recognized for decades. A key driver has been 
the interest in understanding the patterns of terrestrial vegetation productivity and its relationships with global biogeochemical cycles, (Viña, 2004).

Vegetation indices (VIs) to monitor terrestrial landscapes by satellite sensors were first developed in 1970s and have been highly successful in assessing vegetation condition, foliage, cover, phenology, and processes such as evapotranspiration (ET) and primary productivity, related to the fraction of photosynthetically active radiation absorbed by a canopy (fPAR), (Glenn, Huete, Nagler, \& Nelson, 2008).

The advantages of using remote sensing for monitoring terrestrial ecosystems have been well documented in Brazil (B. B. Silva et al., 2013), (J. D. Galvíncio, Pimentel, \& Mendonça, 2012), (Pereira, França, \& Galvincio, 2012), (L. G. da Silva \& Galvincio, 2012), (Moura et al., 2012), and (J. D. Galvíncio, Naue, Angelotti, \& Moura, 2011) and exterior, (Fang, Wei, \& Liang, 2012), (W. Wang et al., 2012), (Liu, Chadwick, Roberts, \& Still, 2011), (Yilmaz, Hunt, \& Jackson, 2008), (Asner \& Warner, 2003), (Knyazikhin, Martonchik, Myneni, Diner, \& Running, 1998) and (Bonan, 1995).

The ratio of leaf surface area to unit ground surface area, called Leaf Area Index (LAI), is a measure of carbon and water balance in plants, because it describes the potential surface area available for leaf gas exchange, (Viña, 2004). LAI is an important parameter controlling many biological and physical processes of the vegetation, including the interception of light and water (rainfall and fog), attenuation of light through the canopy, transpiration, photosynthesis, autotrophic respiration, and carbon and nutrient (e.g. nitrogen, phosphorus, etc) cycles. At low to intermediate densities of vegetation, small increases in LAI can substantially enlarge the potential for whole-plant gas exchange; thus LAI is a major controller of both gross primary production and evapotranspiration of the canopy. At high plant densities, self- shading becomes a limiting factor, and thus increases in LAI do not directly lead to an increment in productivity, (Viña, 2004).

Leaf area index (LAI) and fraction of photosynthetically active radiation (0.4-0.7 Am) absorbed by vegetation (FPAR) characterize vegetation canopy functioning and energy absorption capacity. LAI is defined as one sided green leaf area per unit ground area in broadleaf canopies and as the projected needle leaf area in coniferous canopies(Sea et al., 2011). LAI and FPAR are key parameters in most ecosystem productivity models and global models of climate, hydrology, biogeochemistry and ecology, (Myneni et al., 2002).

The global savanna biome is characterized by enormous diversity in the physiognomy and spatial structure of the vegetation, (Hill et al., 2011). Savannas are fundamentally two-layer vegetation systems with a grassland understorey overlaid with a variable density of shrubs and trees in both a continuum and a patch arrangement: if the woody plants are absent then the land cover should be classified as grassland, and if the woody plants are so dense that the grasses are absent then the land cover should be classified as shrub land or forest. As two-layer vegetation systems they provide one of the most complex problems for retrieval of vegetation properties from remote sensing and consequently very specific difficulties in relation to modeling, and coupling remote sensing with modeling.(Hill et al., 2011).

Savannas are defined as tropical and sub-tropical vegetation types where woody plants and grasses codominate. They are characterized by a seasonal change of water availability with distinct rainy and dry seasons. Decades of research have identified not only water, but also nutrients, herbivory, and fire as major drivers of savanna vegetation dynamics,(Kutsch et al., 2008).

The importance of LAI estimates for ecosystem monitoring and assessment of vegetation dynamics was well known, and these estimates are of paramount importance for the understanding of ecosystem productivity and climatology, hydrology, biogeochemistry process and ecology. Move towards increasingly improve these estimates will always be of interest to the scientific community.

It is known that many of the equations used to estimate LAI are resulting of calibration in irrigated area where vegetation is with great water conditions. These equations are not suitable for estimating LAI in dry forest, as in the case of forests found in the semiarid region of Northeast Brazil (Caatinga). To improve these equations, an alternative that has been applied in the present data is obtained from field spectroradiometry and portable meters of LAI. These methods have the advantages of not being destructive and so obtaining a large sample of data and improving a statistical evaluation of the data and models developed.

Given the above, this study aims to develop an equation of LAI calibrated by savannah in semiarid northeastern Brazil and proposed a model to better 
estimate the LAI for dry forest, such as the savanna (Caatinga).

\section{Materials and Methods}

\section{Study Area}

The spatial location of the research sites under study is in the municipalities of Petrolina and Serra Talhada in the state of Pernambuco, Northeastern Brazil, Fig. 1.

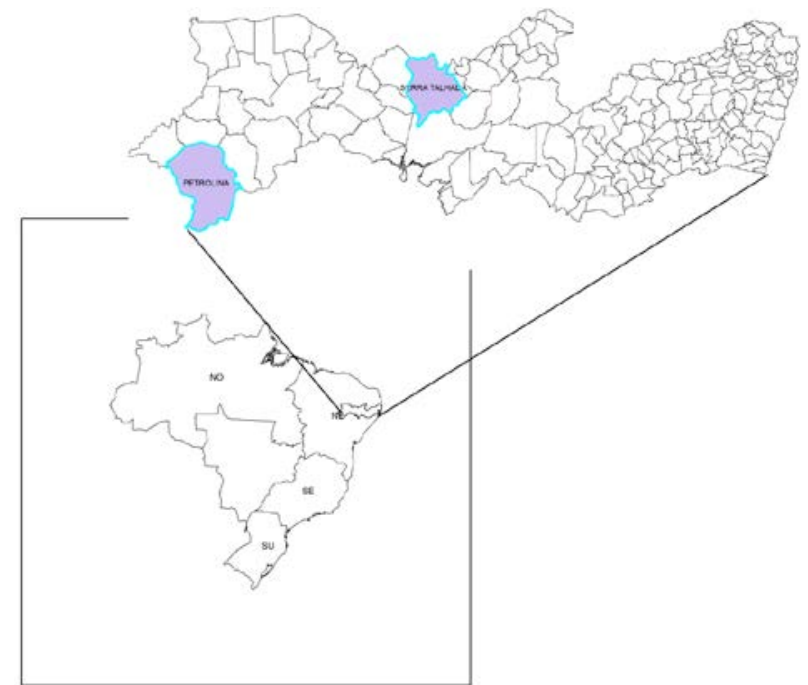

FIG. 1 SPATIAL LOCATION OF THE MUNICIPALITIES SERRA TALHADA AND PETROLINA IN BRAZIL.

\section{Field Data}

Data were collected on a grid $500 \times 500$ meters, which corresponds to an area of $250,000 \mathrm{~m} 2$ per site. A total of two sites, one in Serra Talhada and another in Petrolina, each was divided into a grid of $5 \times 5$ or 25 sampling points. In 32 samples reflectance data and LAI were obtained. These data varied temporally and spatially corresponding to days: 05/19/2011, 06/14/2011 to $06 / 16 / 2011,03 / 15 / 2012$ to $05 / 17 / 2012$, $11 / 22 / 2012$, November/28 and 29/2012, 02 and 03 of the April of 2013, Long Term Ecological Program-LTER, sites, in Brazil PELD, obtained in Petrolina and Serra Talhada.

\section{Spectral Reflectance Data}

Spectral reflectance was measured between 336 and $1045 \mathrm{~nm}$ with a spectral resolution of $1 \mathrm{~nm}$, covering visible and near-infrared portions of the electromagnetic spectrum. Fieldspec HandHeld (ASD, Boulder, USA) fitted with a fiber optic probe having a $25^{\circ}$ field of view was used. The spectroradiometer was optimized using reference white plate(Josiclêda D Galvíncio, Naue, Angelotti, \& Moura, 2011).

\section{Leaf Area Index}

Leaf area index (LAI) was measured using a plant canopy analyzer (Accupar, Decagon Devices, Inc. 2365 NE Hopkins Ct. Pullman, WA 99163-USA), which estimates LAI based on attenuation of light by the canopy at various angles. The Accupar is a linear ceptômetro used to measure light interception in plant canopies and to calculate the leaf area index. Contains 80 independent sensors $(1 \mathrm{~cm})$. It was measures photosynthetically active radiation $(400-700 \mathrm{~nm})$ with a range from 0 to $2.500 \mu \mathrm{mol} / \mathrm{m}^{2} \mathrm{~s}$. The resolution is 1 $\mu \mathrm{mol} / \mathrm{m}^{2} \mathrm{~s}$.

\section{IKONOS Satellite Data}

The IKONOS satellite data were acquired for the PELD, site 22, (http://www.ufpe.br/sercaatinga). The data were delivered in a geo-registered, UTM projection with 11-bit radiometric resolution.

The image used data corresponding to $08 / 26 / 2008$, with azimuth 49.7925, 60.79709 elevation and time of satellite passage: 13: 13 GMT. The IKONOS satellite sensor has a spatial resolution of $1 \mathrm{~m}$. This image covers the area of the site 22 of PELD in Petrolina. The area located in savanna (Caatinga) preserved of the Embrapa Tropical semiarid, with coordinates (09oㅜ 09 'S latitude and $40^{\circ} 22^{\prime} \mathrm{W}$ longitude), Fig. 2.

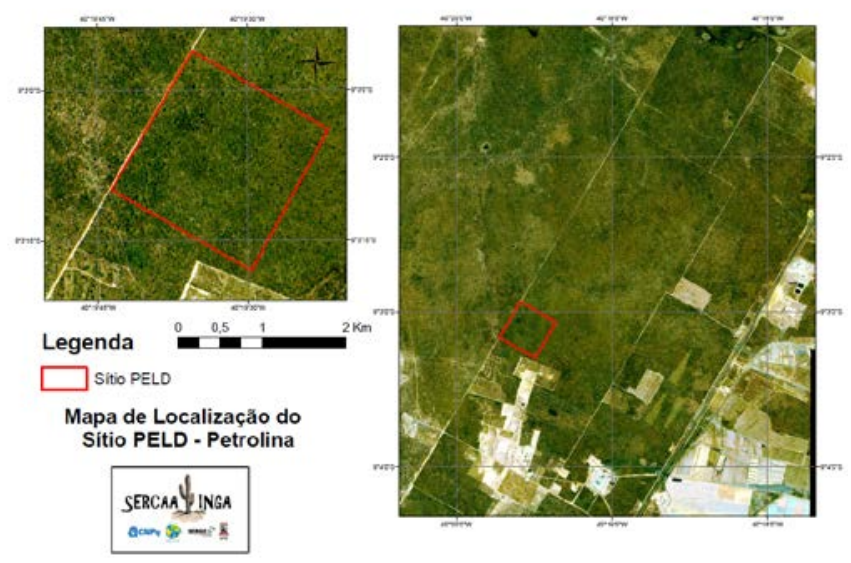

FIG. 2 IKONOS IMAGE, SITE 22, PELD, PETROLINA-PE.

\section{NDVI-Normalized Difference Vegetation Index}

The reflectance data was obtained NDVI using average reflectance from 630 to $700 \mathrm{~nm}$ (red) and mean reflectance between 760 to $850 \mathrm{~nm}$ (near infrared).

\section{Test Methods}

Linear regression was applied and tested in the following models: Linear (1), Logarithmic (2), Inverse (3), Quadratic (4), Cubic (5), Compound (6), Power (7), $S$ (8), Growth (9) and Exponential (10).

\section{1) Linear}

Model whose equation is 


$$
\mathrm{Y}=\mathrm{b} 0+(\mathrm{b} 1 * \mathrm{t})
$$

The series values are modeled as a linear function of time.

\section{2) Logarithmic}

Model whose equation is

$$
\mathrm{Y}=\mathrm{b} 0+(\mathrm{b} 1 * \ln (\mathrm{t}))
$$

\section{3) Inverse}

Model whose equation is

$$
\mathrm{Y}=\mathrm{b} 0+(\mathrm{b} 1 / \mathrm{t})
$$

\section{4) Quadratic}

Model whose equation is

$$
\mathrm{Y}=\mathrm{b} 0+(\mathrm{b} 1 * \mathrm{t})+\left(\mathrm{b} 2 * \mathrm{t}^{* *} 2\right)
$$

The quadratic model can be used to model a series that "takes off" or a series that dampens.

\section{5) Cubic}

Model that is defined by the equation

$$
Y=b 0+(b 1 * t)+\left(b 2 * t^{* *}\right)+\left(b 3 * t^{* *} 3\right)
$$

\section{6) Power}

Model whose equation is

$$
\mathrm{Y}=\mathrm{b} 0 *\left(\mathrm{t}^{* *} \mathrm{~b} 1\right) \text { or } \ln (\mathrm{Y})=\ln (\mathrm{b} 0)+\left(\mathrm{b} 1^{*} \ln (\mathrm{t})\right)
$$

\section{7) Compound}

Model whose equation is

$$
\mathrm{Y}=\mathrm{b} 0 *(\mathrm{~b} 1 * \mathrm{t}) \text { or } \ln (\mathrm{Y})=\ln (\mathrm{b} 0)+(\ln (\mathrm{b} 1) * \mathrm{t})
$$

\section{8) S-curve}

Model whose equation is

$$
\mathrm{Y}=\mathrm{e}^{* *}(\mathrm{~b} 0+(\mathrm{b} 1 / \mathrm{t})) \text { or } \ln (\mathrm{Y})=\mathrm{b} 0+(\mathrm{b} 1 / \mathrm{t})
$$

\section{9) Growth}

Model whose equation is

$$
\mathrm{Y}=\mathrm{e}^{* *}(\mathrm{~b} 0+(\mathrm{b} 1 * \mathrm{t})) \text { or } \ln (\mathrm{Y})=\mathrm{b} 0+(\mathrm{b} 1 * \mathrm{t})
$$

\section{0) Exponential}

Model whose equation is

$$
\mathrm{Y}=\mathrm{b} 0 *\left(\mathrm{e}^{* *}(\mathrm{~b} 1 * \mathrm{t})\right) \text { or } \ln (\mathrm{Y})=\ln (\mathrm{b} 0)+(\mathrm{b} 1 * \mathrm{t}) \quad(10)
$$

Where $\mathrm{Y}$ is dependent variable (estimated) (This study, LAI), b0 and b1 are constant, $t$ is independent variable (This study, NDVI).

To evaluate the models, we used the Pearson correlation coefficients (r), coefficient of determination $\left(r^{2}\right)$, Ajusted $r^{2}$, Std Error of the Estimate, Sum of Squares, difference (df), Mean Square, F- degrees of Freedom and significance level.

After choosing the model that best fitted the data observed, LAI was made to estimate LAI with the new model.

The new model development in this study was compared with the model by (Bastiaanssen, 1995) in SEBAL (Surface Energy Balance Algorithm for Land) model. We calculated the absolute error between the LAI estimated and observed.

\section{Aplication of the New Model in IKONOS Image}

The new model was applied to the IKONOS image configuration described in item 2.5. The equations used for radiometric calibration and of reflectance are presented below.

\section{Radiometric calibration of the IKONOS}

The radiometric calibration of satellite sensors IKONOS can be obtained by Equation 11:

$$
L_{\lambda}=\frac{10^{4} \mathrm{DN}_{\lambda}}{\text { Coef }_{\lambda} \text { BandaWith }_{\lambda}}
$$

where $\mathrm{DN}_{\lambda}$ is digital number in band $\lambda$, Coef $\lambda$ and Banda with $\lambda$ are the coefficient of calibration in band $\lambda$, Table 1.

TABLE 1 RADIOMETRIC CALIBRATION COEFFICIENT OF BY BAND.

\begin{tabular}{c|c|c|c}
\hline Wavelength $(\mu \mathrm{m})$ & $\begin{array}{c}\text { Calibration } \\
\text { coefficient }\end{array}$ & $\begin{array}{c}\text { Band } \\
\text { with } \lambda\end{array}$ & $\begin{array}{c}\text { Esun } \lambda \\
\left(\mathrm{Wm}^{-2} \mathrm{~m}^{-1}\right)\end{array}$ \\
\hline Band 1 $(0,45-0,52)$ & 728 & 71,3 & 1930,9 \\
\hline Band 2 $(0,51-0,60)$ & 727 & 88,6 & 1854,8 \\
\hline Band 3 $(0,63-0,70)$ & 949 & 65,8 & 1556,5 \\
\hline Band 4 $(0,76-0,85)$ & 843 & 95,4 & 1156,5 \\
\hline Pan & 161 & 403 & 1375,8 \\
\hline
\end{tabular}

\section{Reflectance}

The reflectance was estimated by Equation 12

$$
L_{\lambda}=\frac{\pi L_{\lambda} d^{2}}{\operatorname{ESUN}_{\lambda} \operatorname{Cos} Z}
$$

where $\mathrm{L}_{\lambda}$ is spectral radiance in band $\lambda, E S U N_{\lambda}$ is spectral irradiance of each band at the top of the atmosphere $\left(\mathrm{Wm}^{-2} \mu \mathrm{m}^{-1}\right.$, Table 1$), \mathrm{Z}$ is solar zenith angle and $\mathrm{d}^{2}$ is square of the average distance EarthSun and estimated by:

$$
d_{r}=1+0,033 \cos (D S A .2 \pi / 365)
$$

where DSA represents the day of the year sequential and cos is rad. The mean value year $\left(\mathrm{d}_{\mathrm{r}}\right)$ is 1 (one). This value $d_{r}$ can fluctuate between 0.97 and 1.03.

\section{Results and discussion}

We evaluated the ten models proposed in tis study. The model that best fit was S-curve with $\mathrm{r}=0.781$ (Table 1). It can be said that there is a strong 
correlation between NDVI and LAI. The NDVI is sensitive to changes in leaf area, pigments and water relations in plants(Moura et al., 2012). A marked relationship has been observed between FAPAR (Fraction of Absorbed Photosynthetically Active Radiation) and NDVI, (R2 = 0.923). In this study, the new model development taking into account the NDVI and FAPAR, is a model based on natural physical processes. Thus, it is suggested that the proposed model is great to evaluate the dynamic variations of natural ecosystem in study. (Moura et al., 2012) claimed that it is necessary to analyze the relationship under different weather conditions and the state of the vegetation to be more confident with the results, since the savanna vegetation has deciduous species and their behavior depends on the availability of soil water.

Models based on physical processes proved to be a promising alternative to describe the transfer and interactions of radiation inside the canopy based on physical laws and thus providing an explicit connection between the biophysical variables and canopy reflectance (Galvincio, Moura, Silva, Silva, \& Naue, 2013).

TABLE 2 MODEL SUMMARY

\begin{tabular}{cccc}
\hline R & R Square & Adjusted R Square & Std. Error of the Estimate \\
\hline .781 & .609 & .596 & .270 \\
\hline \multicolumn{4}{c}{ The independent variable is NDVI. }
\end{tabular}

Table 2 displays a summary analysis of variance for selected model. Note that the sum of squared errors is equal to 3.401 in the regression, the difference is 1 and the degrees of Freedom is 46.800 with a significance level of 0.00 .

TABLE 3 ANOVA

\begin{tabular}{c|c|c|c|c|c}
\hline & Sum of Squares & $\mathrm{df}$ & Mean Square & $\mathrm{F}$ & Sig. \\
\hline Regression & 3.401 & 1 & 3.401 & 46.800 & .000 \\
\hline Residual & 2.180 & 30 & .073 & & \\
\hline Total & 5.582 & 31 & & & \\
\hline \multicolumn{3}{l}{ The independent variable is NDVI. }
\end{tabular}

TABLE 4 COEFFICIENTS

\begin{tabular}{l|c|c|c|c|c}
\hline & \multicolumn{2}{c}{$\begin{array}{c}\text { Unstandardized } \\
\text { Coefficients }\end{array}$} & $\begin{array}{c}\text { Standardized } \\
\text { Coefficients }\end{array}$ & $\mathrm{t}$ & Sig. \\
& $\mathrm{B}$ & Std. Error & Beta & & \\
\hline 1 1 NDVI & -.542 & .079 & -.781 & -6.841 & .000 \\
\hline (Constant) & 1.426 & .172 & & 8.312 & .000 \\
\hline
\end{tabular}

The dependent variable is $\ln$ (Leaf Area Index [LAI]).

The coefficients of the equation are shown in Table 3. According to the data, the LAI can be estimated by the following equation:

$$
\mathrm{LAI}=\operatorname{EXP}(1.426+(-0.542 / \mathrm{NDVI})
$$

where 1.426 is constant $b 0$ and -0.542 is constant $b 1$.
Or

$$
\operatorname{Ln}(\mathrm{LAI})=1.426+(-0.542 / \mathrm{NDVI})
$$

The relationship between NDVI and LAI with MODIS images, in forest sites from western oceanic to continental zones, and from boreal to Mediterranean countries was examined by (Q. Wang, Adiku, Tenhunen, \& Granier, 2005). The results of this study were high correlations in period of the leaf in plant and low correlation when no leaf in plant. It was shown that possible reasons for this would be background reflectance following snowmelt. Thus, although the NDVI-LAI relations were good for the individual years for the leaf production stage $\left(\mathrm{R}^{2}\right.$ were $0.99,0.99$, and 0.98 ), the relationship was poor when all the data were pooled over years $\left(\mathrm{R}^{2}\right.$ of 0.03$)(\mathrm{Q}$. Wang et al., 2005). This may be attributed to the fact that each individual year has a different background NDVI, which should be corrected before applying the NDVI data over years. Indeed, when the background NDVI was corrected before pooling the data, the LAINDVI relation was improved and the following was the result for relative NDVI and LAI during the leaf production period.

This discussion is important because errors in the savanna of the relationship NDVI and LAI are similar. In special in this study by reason of caatinga losing their leaves in the dry. Many of the models are great in rainy season but err for the dry period.

The relationship between observed values and estimated LAI can be seen in Figure 3. In general, the new model accompanying with change in LAI observed. The Mean Square Error for the new model was 0.10 .

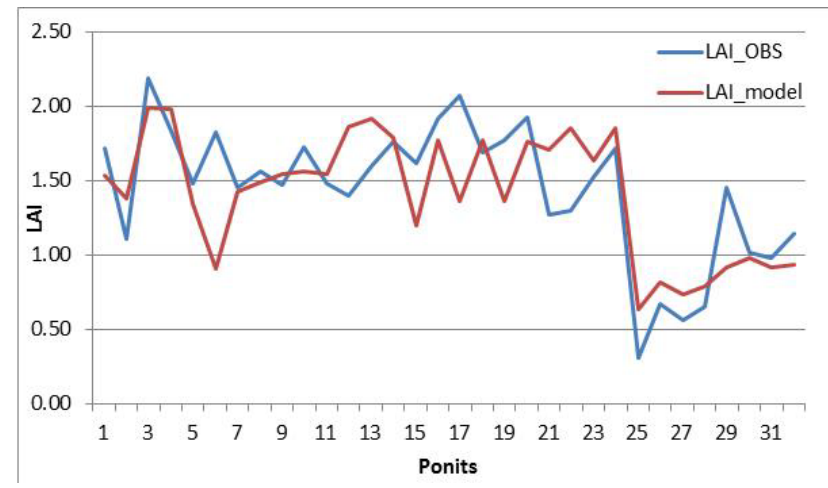

FIG. 3 RELATIONSHIP BETWEEN OBSERVED AND MODEL LAI.

In study of (Li \& Wang, 2013) four types of indices for deriving canopy LAI were examined. The results revealed that all the identified best indices had the wavelength combinations ( $\lambda 1$ and $\lambda 2$ ) within the 900 $1100 \mathrm{~nm}$ domain. It had an Root Mean Square Error (RMSE) of $0.62,0.85,0.96$, and $1.22 \mathrm{~m}^{2} / \mathrm{m}^{2}$, and a BIAS 
of $0.42,0.47,0.55$, and $1.01 \mathrm{~m}^{2} / \mathrm{m}^{2}$ for simulated datasets.

Table 4 shows value of LAI estimated (new model and SEBAL) and observed and error of new model and SEBAL.

Table 5 value of observed and estimated leaf area index (new model and SEBAL) and absolute errors of estimated.

\begin{tabular}{|c|c|c|c|c|}
\hline $\begin{array}{c}\text { Leaf Area Index } \\
{[\mathrm{LAI}]}\end{array}$ & $\begin{array}{l}\text { LAI New } \\
\text { model }\end{array}$ & $\begin{array}{c}\text { LAI } \\
\text { Sebal }\end{array}$ & $\begin{array}{l}\text { Error } \\
\text { Sebal }\end{array}$ & $\begin{array}{l}\text { Error New } \\
\text { model }\end{array}$ \\
\hline 1.72 & 1.532486 & 0.17255 & 1.54745 & 0.187514 \\
\hline 1.11 & 1.377083 & 0.294847 & 0.815153 & -0.26708 \\
\hline 2.19 & 1.986452 & 1.059161 & 1.130839 & 0.203548 \\
\hline 1.84 & 1.984388 & 1.056123 & 0.783877 & -0.14439 \\
\hline 1.48 & 1.344119 & 0.194006 & 1.285994 & 0.135881 \\
\hline 1.83 & 0.911027 & 0.094412 & 1.735588 & 0.918973 \\
\hline 1.45 & 1.428 & 0.313593 & 1.136407 & 0.022 \\
\hline 1.56 & 1.489318 & 0.253545 & 1.306455 & 0.070682 \\
\hline 1.47 & 1.54762 & 0.17176 & 1.29824 & -0.07762 \\
\hline 1.73 & 1.559975 & 0.299082 & 1.430918 & 0.170025 \\
\hline 1.48 & 1.542821 & 0.266588 & 1.213412 & -0.06282 \\
\hline 1.4 & 1.865484 & 0.525775 & 0.874225 & -0.46548 \\
\hline 1.6 & 1.921666 & 0.481509 & 1.118491 & -0.32167 \\
\hline 1.76 & 1.792904 & 0.541882 & 1.218118 & -0.0329 \\
\hline 1.62 & 1.20032 & 0.195214 & 1.424786 & 0.41968 \\
\hline 1.92 & 1.768639 & 0.166038 & 1.753962 & 0.151361 \\
\hline 2.07 & 1.361062 & 0.2834 & 1.7866 & 0.708938 \\
\hline 1.69 & 1.768639 & 0.166038 & 1.523962 & -0.07864 \\
\hline 1.77 & 1.361062 & 0.2834 & 1.4866 & 0.408938 \\
\hline 1.93 & 1.760243 & 0.348163 & 1.581837 & 0.169757 \\
\hline 1.27 & 1.712505 & 0.417355 & 0.852645 & -0.4425 \\
\hline 1.3 & 1.849692 & 0.452062 & 0.847938 & -0.54969 \\
\hline 1.53 & 1.635197 & 0.346178 & 1.183822 & -0.1052 \\
\hline 1.72 & 1.851896 & 0.087054 & 1.632946 & -0.1319 \\
\hline 0.31 & 0.63024 & -0.00539 & 0.315388 & -0.32024 \\
\hline 0.67 & 0.818731 & 0.076402 & 0.593598 & -0.14873 \\
\hline 0.56 & 0.730442 & 0.000589 & 0.559411 & -0.17044 \\
\hline 0.65 & 0.78498 & 0.126754 & 0.523246 & -0.13498 \\
\hline 1.45 & 0.920525 & 0.246092 & 1.203908 & 0.529475 \\
\hline 1.02 & 0.980852 & 0.319665 & 0.700335 & 0.039148 \\
\hline 0.98 & 0.919669 & 0.278617 & 0.701383 & 0.060331 \\
\hline 1.14 & 0.937536 & 0.272295 & 0.867705 & 0.202464 \\
\hline Média $=1.444375$ & 1.414862 & 0.305774 & 1.138601 & 0.029513 \\
\hline
\end{tabular}

Note that the absolute error of the New model was 0.029 and the absolute error of SEBAL was 1.138. RMSE for SEBAL 1.44 and the new model 0.10 have yet been obtained. Note that the new model provides a better estimate of LAI when compared with the SEBAL. Statistical result similar to that found in this study was obtained from calibrating the Eucalyptus LAI for MODIS images. The authors obtained a coefficient of determination of 0.68 with a significance level of 0.001(Le Maire, Marsden, Nouvellon, Stape, \& Ponzoni, 2012).

Indirect determination of LAI, as an important measure of canopy structure, is affected by clumping of needles in conifer species and to a lesser extent of leaves in deciduous species. Clumping seems to be the main factor causing errors in the LAI estimation, (Jonckheere et al., 2004).

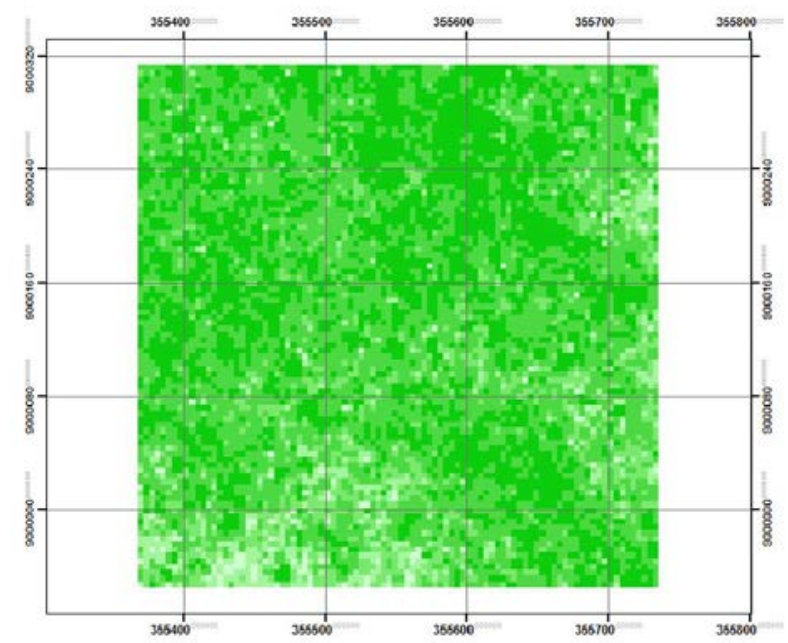

\section{Legend}

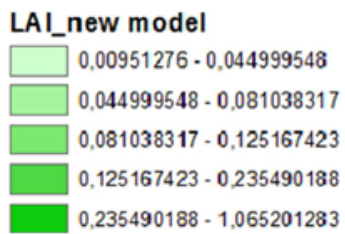

FIG. 4 LAI NEW MODEL.

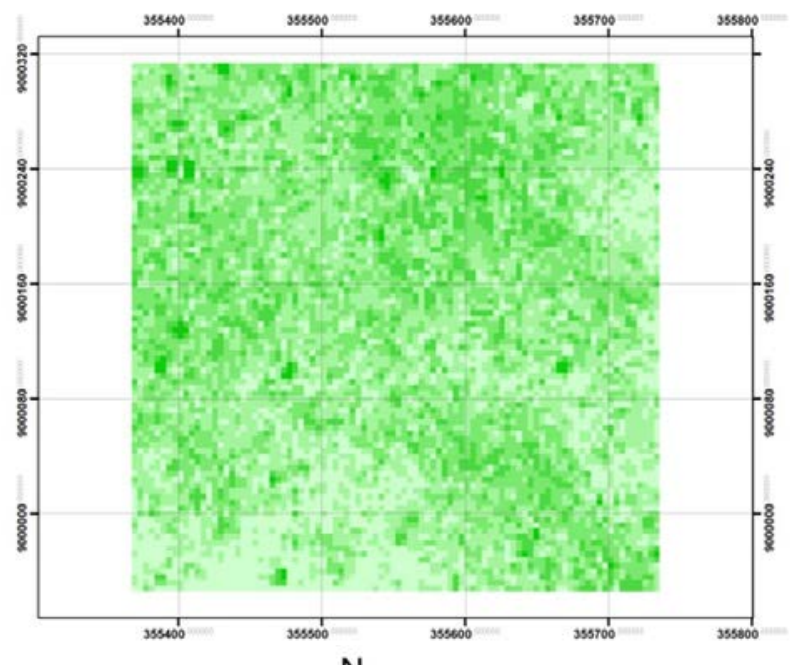

\section{Legend}

$\square \cdot 0,060195886 \cdot 0,038337551$
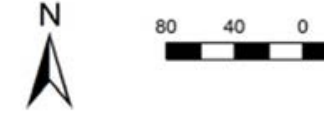

FIG. 5 LAI SEBAL

\section{IKONOS}

LAI was estimated using the new model (Fig. 4) and the model proposed in SEBAL (Fig. 5) in IKONOS 
image. In general, the new model presented LAI greater than 0.12 while the LAI estimated from the formula proposed by SEBAL was less than 0.08 . Comparing Figs. 4 and 5 to Fig. 2, it is noted that the new model has values more consistent with reality than the LAI estimated with SEBAL.

The spatial relation between the values of the new model and SEBAL is showed in Fig 6, indicating a relation of $\mathrm{r}^{2}=0.977$, ie, physically the two models respond spatial variations of LAI in the local. However, the new model proposed here best represents the quantitative value of LAI spatially.

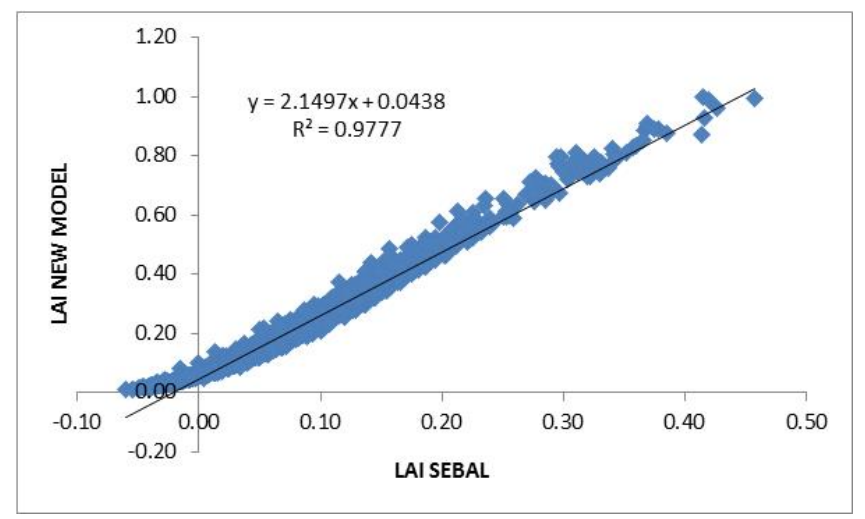

FIG. 6 RELATIONSHIP BETWEEN LAI NEW MODEL AND LAI SEBAL.

The study took place in an evergreen scrub oak ecosystem in Florida (Pontailler, Hymus, \& Drake, 2003). Vegetation reflectance was measured in situ with a laboratory-made sensor in the red $(640-665 \mathrm{~nm})$ and near-infrared (750-950 nm) bands to calculate the normalized difference vegetation index (NDVI) and derive the leaf area index (LAI). LAI estimates from this technique were compared with two other nondestructive techniques, intercepted photosynthetically active radiation (PAR) and hemispherical photographs, in four contrasting $4 \mathrm{~m} 2$ plots in February 2000 and two $4 \mathrm{~m} 2$ plots in June 2000. Beer's law was employed to derive LAI from PAR interception and gap fraction distribution to derive LAI from photographs. The plots were harvested manually after the measurements to determine a "true" LAI value and to calculate a light extinction coefficient $(\mathrm{k})$. The technique based on Beer's law was affected by a large variation of the extinction coefficient, owing to the larger impact of branches in winter when LAI was low. Hemispherical photographs provided satisfactory estimates, slightly overestimated in winter because of the impact of branches or underestimated in summer because of foliage clumping. NDVI provided the best fit, showing only saturation in the densest plot (LAI = 3.5). It was concluded that in situ measurement of NDVI is an accurate and simple technique to nondestructively assess LAI in experimental plots or in crops if saturation remains acceptable(Pontailler et al., 2003).

Leaf area index (LAI) is a key variable functionally related to plant biomass production. Accurate estimation of LAI is important for monitoring vegetation dynamics, and LAI information is essentially required for the prediction of microclimate and various biophysical processes within and below canopy(Fan, Gao, Brück, \& Bernhofer, 2008). The traditional, direct and destructive method of measuring LAI is time-consuming. Modern gap fraction technique can assess LAI fast and easily, however, its application is problematic with vegetations of low stature. Alternatively, NDVI (Normalized Difference Vegetation Index) as a widely used spectral reflectance index has been shown to be a good estimator of LAI to estimate LAI indirectly. In situ measurements of NDVI and LAI at three sites in semiarid grassland in Inner Mongolia, China were carried out during the growing season. Based on these sites, a general linear and exponential relationship were developed, which can be used for various grazing intensity grasslands and also for higher vegetation cover area (e.g. wetland) in the region. Thesituation similar in dry forest in Nordeste of the Brazil was investigated. An equation was developed that can be used for estimating LAI suitable for the natural range of vegetation in this area during the growing season under both normal and dry weather conditions. By simply applying NDVI measurements and these relation- ships, the vegetation status and grass yield in the area will be rapidly and nondestructively estimated, which is helpful for livestock management and sustainable land use.

\section{Conclusions}

The model developed in this study may be used to improve the estimates of Leaf Area Index [LAI] in dry forest with NDVI. We have developed one model for savanna-specific of leaf area index (LAI).

The use of S Curve statistical methods to calibrate the leaf area index (LAI) was proved to be efficient.

The model development gave good results in most of the LAI range known for Caatinga stands in Nordeste of Brazil. The Root Mean Square Error (RMSE) calculated on an independent LAI dataset was 0.10, which is about $6 \%$ of the average measured LAI. However, high LAI values were still difficult to retrieve with such an index. The indices were tested 
on a dataset showing a large range of climate conditions. In addition, validation on a larger dataset would be useful to confirm their accuracy.

\section{ACKNOWLEDGMENTS}

Conselho Nacional de Desenvolvimento Científico e Tecnológico (CNPQ) by financial research aid through project 588074/2009-0, the Long Term Ecological Program-LTER and the research grant given to the first author.

\section{REFERENCES}

Asner, G. P., \& Warner, A. S. Canopy shadow in IKONOS satellite observations of tropical forests and savannas. Remote Sensing of Environment, 87(4), 521-533. (2003). doi:10.1016/j.rse.2003.08.006.

Bastiaanssen, W. G. M. Regionalization of surface flux densities and moisture indicators in composite terrain. Landbouw universiteite Wangeningen. (1995).

Bonan, B. Land-atmosphere $\mathrm{COz}$ exchange simulated by a land surface. Journal of Geophysical Research, 100(D2), 2817-2831. (1995).

Eagleson, P. S., \& Segarra, R. I. Water-Limited Equilibrium of Savanna Vegetation Systems. Water Resources Research, 21(10), 1483-1493. (1985), doi:10.1029/WR021i010p01483.

Fan, L., Gao, Y., Brück, H., \& Bernhofer, C. Investigating the relationship between NDVI and LAI in semi-arid grassland in Inner Mongolia using in-situ measurements. Theoretical and Applied Climatology, 95(1-2), 151-156. (2008). doi:10.1007/s00704-007-0369-2.

Fang, H., Wei, S., \& Liang, S. Validation of MODIS and CYCLOPES LAI products using global field measurement data. Remote Sensing of Environment, 119, 43-54.(2012). doi:10.1016/j.rse.2011.12.006.

Galvincio, J. D., Moura, M. S. B. De, Silva, T. G. F. da, Silva, B. B. da, \& Naue, C. R. (2013). RELATIONSHIP BETWEEN CANOPY AND LEAF SPECTRAL. Remote Sensing of Environment, (submission), 1-22.

Galvíncio, J. D., Naue, C. R., Angelotti, F., \& Moura, M. S. B. De. Vitis vinifera SPECTRAL RESPONSE TO THE INCREASE OF CO 2. Journal of Hyperspectral Remote Sensing, 01(01), 1-18.(2011). doi:10.5935/2237-2202.20110001.

Galvíncio, J. D., Pimentel, \& Mendonça, R. M. de. LEAF SPECTRAL BEHAVIOR AND CHLOROPHYLL
CONTENT OF MIMOSA HOSTILIS CANOPY IN A SEMIARID ENVIRONMENT. Journal of Hyperspectral Remote Sensing, 02(01), 001-009. (2012). doi:10.5935/22372202.20120001.

Galvíncio, Josiclêda D, Naue, C. R., Angelotti, F., \& Moura, M. S. B. De. (2011). Vitis vinifera SPECTRAL RESPONSE TO THE INCREASE OF CO 2. Journal of Hyperspectral Remote Sensing, 01, 1-18. (2011). Retrieved from http://www.revista.ufpe.br/jhrs/index.php/revista/article/ view/2/1.

Giambelluca, T. W., Scholz, F. G., Bucci, S. J., Meinzer, F. C., Goldstein, G., Hoffmann, W. a., Franco, A. C., et al. Evapotranspiration and energy balance of Brazilian savannas with contrasting tree density. Agricultural and Forest Meteorology, 149(8), 1365-1376. (2009). doi:10.1016/j.agrformet.2009.03.006.

Glenn, E. P., Huete, A. R., Nagler, P. L., \& Nelson, S. G. Relationship between remotely-sensed vegetation indices, canopy attributes, and plant physiological processes: what vegetatio, 2136-2160. (2008).

Higgins, S. I., Bond, W. J., \& Trollope, W. S. W. Fire, resprouting and variability: a recipe for grass-tree coexistence in savanna. Journal of Ecology, 88(2), 213-229. (2000). doi:10.1046/j.1365-2745.2000.00435.x.

Hill, M. J., Román, M. O., Schaaf, C. B., Hutley, L., Brannstrom, C., Etter, A., \& Hanan, N. P. Characterizing vegetation cover in global savannas with an annual foliage clumping index derived from the MODIS BRDF product. Remote Sensing of Environment, 115(8), 2008-2024. (2011). doi:10.1016/j.rse.2011.04.003.

House, J. I., Archer, S., Breshears, D. D., Scholes, R. J., Tree, N., Interactions, G., \& Max, P. Conundrums in mixed woody - herbaceous plant systems, 1763-1777. (2003).

Jonckheere, I., Fleck, S., Nackaerts, K., Muys, B., Coppin, P., Weiss, M., \& Baret, F. Review of methods for in situ leaf area index determination. Agricultural and Forest Meteorology, 121(1-2), 19-35. (2004). doi:10.1016/j.agrformet. 2003.08.027.

Knyazikhin, Y., Martonchik, J. V., Myneni, R. B., Diner, D. J., \& Running, S. W. Synergistic algorithm for estimating vegetation canopy leaf area index and fraction of absorbed photosynthetically active radiation from MODIS and MISR data. Journal of Geophysical Research, 
103(D24), 32257. (1998). doi:10.1029/98JD02462.

Kutsch, W. L., Hanan, N., Scholes, B., McHugh, I., Kubheka, W., Eckhardt, H., \& Williams, C. Response of carbon fluxes to water relations in a savanna ecosystem in South Africa. Biogeosciences, 5(6), 1797-1808. (2008). doi:10.5194/ bg-5-1797-2008.

Le Maire, G., Marsden, C., Nouvellon, Y., Stape, J.-L., \& Ponzoni, F. Calibration of a Species-Specific Spectral Vegetation Index for Leaf Area Index (LAI) Monitoring: Example with MODIS Reflectance Time-Series on Eucalyptus Plantations. Remote Sensing, 4(12), 3766-3780. (2012). doi:10.3390/rs4123766.

Li, P., \& Wang, Q. Developing and validating novel hyperspectral indices for leaf area index estimation: Effect of canopy vertical heterogeneity. Ecological Indicators, 32, 123-130. (2013). doi:10.1016/j.ecolind.2013. 03.025.

Liu, S., Chadwick, O. a., Roberts, D. a., \& Still, C. J. Relationships between GPP, Satellite Measures of Greenness and Canopy Water Content with Soil Moisture in Mediterranean-Climate Grassland and Oak Savanna. Applied and Environmental Soil Science, 2011, 114. (2011). doi:10.1155/2011/839028.

Miranda, a. C., Miranda, H. S., Lloyd, J., Grace, J., Francey, R. J., Mcintyre, J. a., Meir, P., et al. Fluxes of carbon, water and energy over Brazilian cerrado: an analysis using eddy covariance and stable isotopes. Plant, Cell and Environment, 20(3), 315-328. (1997). doi:10.1046/j.13653040.1997.d01-80.x

Moura, M. S. B. de, Galvincio, J. D., Silva, B. B., Machado, C. C. C., Silva, H. A. da, \& Oliveira, T. H. de. Gross primary production using related vegetation indices. $A n A S A B E$ Meeting Presentation, 7004(11), 1-11. (2012).

Myneni, R. ., Hoffman, S., Knyazikhin, Y., Privette, J. ., Glassy, J., Tian, Y., Wang, Y., et al. Global products of vegetation leaf area and fraction absorbed PAR from year one of MODIS data. Remote Sensing of Environment, 83(1-2), 214-231. (2002). doi:10.1016/S0034-4257(02)000743.

Pereira, J. A. dos S., França, L. M. de A., \& Galvincio, J. D. RELATIONSHIP BETWEEN VEGETATION INDICES AND ALTIMETRY IN TRIUNFO-PE, BRAZIL. Journal of Hyperspectral Remote Sensing, 02(03), 37-43. (2012).
Pontailler, J.-Y., Hymus, G. J., \& Drake, B. G. Estimation of leaf area index using ground-based remote sensed NDVI measurements: validation and comparison with two indirect techniques. Canadian Journal of Remote Sensing, 29(3), 381-387. (2003). doi:10.5589/m03-009.

Ryu, Y., \& Science, E. Near-surface remote sensing of canopy architecture and land-atmosphere interactions in an oak savanna ecosystem Near-surface remote sensing of canopy architecture and land-atmosphere interactions in an oak savanna ecosystem. University of California, Berkeley. (2010).

Scholes, R. J., \& Archer, S. R. Tree-Grass Interactions in Savannas. Annual Review of Ecology and Systematics, 28, 517-544. (1997).

Sea, W. B., Choler, P., Beringer, J., Weinmann, R. a., Hutley, L. B., \& Leuning, R. Documenting improvement in leaf area index estimates from MODIS using hemispherical photos for Australian savannas. Agricultural and Forest Meteorology, 151(11), 1453-1461. (2011). doi:10.1016/j. agrformet.2010.12.006.

Silva, B. B., Galvíncio, J. D., Montenegro, S. M. G. L., Machado, C. C. C., Oliveira, L. M. M. De, \& Moura, M. S. B. de. DETERMINAÇÃO POR SENSORIAMENTO REMOTO DA PRODUTIVIDADE PRIMÁRIA BRUTA DO PERÍMETRO IRRIGADO SÃO GONÇALO - PB Universidade Federal de Pernambuco ( UFPE ), Recife, PE , Brasil Empresa Brasileira de Pesquisa Agropecuária ( EMBRAPA ), Petrolina , PE , Brasil. Revista Brasileira de Meteorologia, 28(1), 57-64. (2013).

Silva, L. G. da, \& Galvincio, J. D. Comparative Analysis of Changes in NDVI and SAVI in PELD - 22 - Petrolina - PE, in the First Decade of the XXI Century. Revista Brasileira de Geografia Física, 05(06), 1446-1456. (2012). doi:10.5935/1984-2295.20120085.

Viña, A. REMOTE ESTIMATION OF LEAF AREA INDEX AND BIOMASS IN CORN AND SOYBEAN By Andrés Viña A DISSERTATION Presented to the Faculty of The Graduate College at the University of Nebraska In Partial Fulfillment of Requirements For the Degree of Doctor of Philosophy. University of Nebraska.(2004).

Wang, Q., Adiku, S., Tenhunen, J., \& Granier, A. On the relationship of NDVI with leaf area index in a deciduous forest site. Remote Sensing of Environment, 94(2), 244-255. 
(2005). doi:10.1016/j.rse.2004.10.006

Wang, W., Yao, X., Yao, X., Tian, Y., Liu, X., Ni, J., Cao, W., et al. Estimating leaf nitrogen concentration with threeband vegetation indices in rice and wheat. Field Crops Research, 129, 90-98. (2012). doi:10.1016/j.fcr.2012.01.014.
Yilmaz, M. T., Hunt, E. R., \& Jackson, T. J. Remote sensing of vegetation water content from equivalent water thickness using satellite imagery. Remote Sensing of Environment, 112(5), 2514-2522. (2008). doi:10.1016/j.rse. 2007.11.014. 